\title{
I didn't do that! Contested Definitions of Racialized Youth in the Extra-Judicial Sanctions Program: Uncovering Hidden Voices
}

\author{
Monetta Bailey \\ Behavioural Sciences Program, Social Science Department, \\ Ambrose University
}

\begin{abstract}
Using the frameworks of Critical Race Theory (CRT), and Institutional Ethnography (IE), this paper investigates the process of hearing the cases of racialized immigrant youth who are referred to the Extra-judicial Sanctions program in Calgary, Alberta. I investigate how cultural capital impacts the way in which the youth's cases are adjudicated. I then look at how this racialized cultural capital impacts the process of youth and their families attempting to contest the definitions that are assigned to them during the hearing process. I suggest that in a criminal justice system that fails to acknowledge the value of diverse cultural capital, the EJS process causes symbolic violence to racialized immigrant youth who are not empowered to have their narratives contribute to the official account of their cases.
\end{abstract}

Keywords: Restorative justice, extra-judicial sanctions, cultural capital, youth justice, racialized immigration 


\section{Introduction}

The goal of diverting youth from the formal justice system in Canada is one of the guiding principles outlined in the Youth Criminal Justice Act (YCJA) of 2003. This goal led to the establishment of the Extra-Judicial Sanctions (EJS) Program (Bala, 2003; Bell, 2011). Under this program, youth are diverted from the formal system to a system of community-focused justice that is implemented by youth justice committees (Bell, 2011). Guidelines for the EJS program are textually outlined in the YCJA as well as in provincial policies, as provinces have the authority to establish the programs as they see fit (Alberta Justice and Solicitor General, 2003). In Calgary, Alberta, the Calgary Youth Justice Society (CYJS) is responsible for the implementation of the EJS Program; this body oversees the administration of the program by providing guidance and support for youth justice committees (CYJS, 2008). Missing from the written mandate within the YCJA, as well as on a provincial level and within the CYJS guidelines, is any reference to the issues that youth from immigrant backgrounds may face when they are referred to the EJS program. It has been well documented that immigrant populations face unique challenges in Canada (Kayaalp, 2016; Khanlou, 2008; Oriola \& Adeyanju, 2011; Wortley, 2009; Wortley \& Owusu-Bempah, 2009); therefore, the justice system must acknowledge these challenges to adequately respond to the needs of racialized immigrant youth. In a multicultural country such as Canada, it is critical that the unique needs of immigrant youth in the criminal justice system are addressed.

Previous research has questioned the ability of volunteer-run youth justice committees to support racialized and/or immigrant youth (Gavrielides, 2014). This paper further contributes to this literature by using Critical Race Theory (CRT) and Institutional Ethnography (IE) as theoretical frameworks to investigate the attentiveness of EJS programs in Calgary, Alberta to the unique needs of racialized immigrant youth. By analysing the cases youth justice committees hear with racialized immigrant youth, I highlight the impact of power imbalances during the decision-making process. In order to better understand experiences of navigating the EJS program from the perspective of a culturally diverse population, I also investigated the ways in which immigrant youth and their families engage with the EJS program.

\section{Background}

The EJS Program is sanctioned under the YCJA, which became the governing legislation for youth in Canada in 2003 and remains so today (GOC, 2002). The YCJA emphasizes the use of the principles of restorative justice when dealing with youth offenders (Bell, 2011; Morrison \& Pawlychka, 2012). A key goal of the EJS Program is to 
reserve the formal justice system for the most serious offences, diverting eligible youth to community response initiatives, such as the EJS Program (Bala, 2003; Bell, 2011). To be eligible for the EJS program, the young person must accept responsibility for the offence of which they have been accused. The young person then meets with members from a youth justice committee for a panel hearing, where they and their families discuss the case (Alberta Justice and Solicitor General, 2003). Importantly, panel members are given a police report documenting the young person's offence, which serves as the official account of the incident. A key component of the EJS program is the presence of a parent or guardian during the process, who serves as the young person's advocate. Despite having this advocate, contesting the official police report is often challenging when the young person and their family lack the accepted cultural capital to successfully challenge or contest the account presented to the panel. While most families attempt to present the youth's case in the most positive light, my research shows that the process through which this occurs and the success of challenging the official account of the offense is compromised for racialized immigrant families, compared to non-racialized Canadian-born families under investigation.

\section{Literature Review}

\section{The Importance of Social and Cultural Capital}

Pierre Bourdieu (1977) discusses symbolic capital as capital, such as language, culture, and social capital, which is valued in a social setting or field, such as the justice system. Possessing such required capital gives individuals an advantage when interacting in that field (Bourdieu, 1977, 1984, 2013). Bourdieu (1977) notes that, like any other field, the legal field is structured by social, economic, and linguistic practices that become known only to the participants in this field based on tradition, education, lived experiences, and professional usage (Bourdieu, 1977). The relationship between symbolic capital and the process of racialization and societal racism has been documented. Brondolo, Libretti, Rivera, and Walsemann (2012) note that racism can impact the social capital of peer relations, further impacting the economic and social success of students.

The detrimental effect of racism on social capital has also been investigated in terms of its impact on political participation (Balzarini, 2006), school participation (Caldas \& Cornigans, 2014), and a lack of community connection, which can lead to marginalization and low self-esteem (Barn, 2010). Day and McDonald (2010), for example, demonstrated the impact of social capital and race on job mobility and occupational success. Cui (2015) notes that a racialized habitus often denotes the essentializing nature of branding Chinese Canadians as model minorities in the educational field, noting that the historical impact of institutional and individual racism impact the 
cognitive structures and experiences of Chinese Canadians. Bankston (2004) demonstrates that the use of social capital within the education context is a complex issue, whereby a form of social capital can be beneficial in one setting or field, but harmful in another. Lareau (2015) found that middle-class adults are better able to demonstrate knowledge of the "rules of the game" when navigating the educational system compared to workingclass adults. Brown (2019) highlights the experiences of women of colour pursuing a doctoral degree in Canada, showing that despite not possessing the cultural capital of one parent having such an education, the women in her research were able to draw on mentorship and survival skills, among other types of capital, to succeed. These forms of capital are not traditionally valued within an academic setting.

Critical race theorists have also used these concepts in their analysis of how racialized individuals experience their social world (Gonzales, 2012; Hartmann, 2003; Maristela, 2014; Park, 2012; Yosso, 2005). Many of these discussions have further incorporated the potential harm caused when capital that is held by various racial or ethnic groups is not deemed as desirable. In institutional settings, for example, the rules and regulations that govern the institution serve to reward those who possess the necessary capital, while those who do not will suffer symbolic violence (Bourdieu, 1977; O’Neill, 1998; Shan, 2013). Yosso (2006) notes that cultural capital has been used to assert the belief that some communities are culturally "rich," while others are culturally "poor."

Critical race theorists challenge these taken-for-granted normative expressions of cultural value. Gutzmore (1983), for example, states that the development of terminology, such as "Black youth," was intended to carry with it a form of social capital that has influenced the interaction of those who fit into that category with the society and the criminal justice system. Tomic (2011) and Kayaalp (2016) argue that language often serves as social capital, whereby those residing in Canada and whose first language is not English or French are disadvantaged. Based on these discussions, Moran (2016) and Tomic (2011) suggest rethinking what capital is considered as valuable, whereby the capital possessed by diverse groups is seen as beneficial and desirable. For example, rather than disadvantaging those whose first language is not English or French, the benefits brought when these individuals bring their additional world views and language skills to the larger societal conversation should be recognized.

In order to understand the use of cultural capital in veracious fields, Lamont and Lareau (1988) state that power dynamics that are present in social relations must be understood. For example, when a group's cultural capital is not valued, that group can experience cultural exclusion, such that boundaries are established and entrenched to distinguish between the dominant group and others. One such power dimension is based on self-elimination, whereby those in the disadvantaged position exclude themselves from the mainstream as they "adjust their aspirations to their perceived chances of success" 
(Lamont \& Lareau, 1998, p. 158). Lamont and Lareau (1998) also speak of direct exclusion, such as in cases when those with less valued capital are directly excluded from privileges in society. This present study utilized the concepts of self-elimination and direct exclusion to investigate how racialized immigrant youth who do not hold the desirable cultural capital experience the EJS process.

\section{Restorative Justice and Race in Canada}

Diversion programs have a long history in Canada, from the Alternative Measures program under the Young Offenders Act to the Extra-Judicial Measures and Sanctions Programs under the YCJA (Bell, 2011; Crocker, 2013; Hogeveen, 2005, 2006). Much has been written about the practice of using diversion programs in Nova Scotia, in particular, as the province is home to one of the most developed forms of diversion programs in the country (Archibald \& Llewellyn, 2006; Clairmont \& Kim, 2013). Williams (2013) notes that restorative justice, as practiced in Nova Scotia, has failed to meet the needs of African Nova Scotians due to a lack of clearly outlined anti-racist policies and guidelines. However, few studies have been conducted within the larger Canadian context to look at the impact of race on experiences in diversion programs. Samuels (2014) is one such study, which found that Black youth in Toronto were overrepresented in diversion programs. Hogeveen (2006) notes that in Edmonton, Alberta, restorative justice programs have given youth, who have largely been "othered" in society, a voice.

Globally, however, research suggests that diversion programs must strive to become more attentive to the needs of racialized and/or immigrant groups. Albrecht (2010) notes that societal diversity can lead to miscommunications within the less formal diversion programs, such as panels that take place within the EJS program. Using Asians and Asian Americans as the subject of their analysis, Choi and Severson (2009) argue for an increased cultural competency within restorative justice programs in Canada since a Westernized framework cannot be applied to understandings of such populations in North America. Daly (2000) acknowledges that, for restorative justice programs to reach their full potential, attention needs to be paid to issues of racial and ethnic diversity through policies and guidelines. Furthermore, it is necessary for changes to occur at the systemic level. Both in Canada and globally, the impact and interaction of race, ethnicity, and immigrant status on the EJS program, as well as on restorative justice and other forms of criminal diversion programs more generally, remain largely understudied (Choi \& Severon, 2009; Delgado, 2000; Gavrielides, 2015). 


\section{Theoretical Frameworks}

Critical race theory, or CRT, is used in this paper to examine the interactions between race and the justice system in the Canadian context (Campbell, 2007; De Freitas \& McAuley, 2008; Fernando \& Rinaldi, 2017; James, 2009; Peirone, Maticka-Tyndale, Dbadebo, \& Kerr, 2017; Razak, 2009; Williams, 2013). As socially constructed categories, race and ethnicity become reinforced through norms, laws, and public policies, which reinforce the dominant societal discourse. In order to unmask taken-for-granted assumptions about race and ethnicity, knowledge that is contained in the counter-narratives of racialized groups must be brought to the forefront of everyday discourse (Delgado \& Stefancic, 2017; Milner \& Howard, 2013; Yosso, 2006). These narratives then serve to contest the taken-for-granted definitions represented in dominant discourse. I argue that only when these counter-narratives and contested definitions are heard is it possible to fully understand the cultural capital used by racialized immigrant individuals when interacting with dominant groups.

Institutional Ethnography, or IE, is a method of inquiry that aims to unmask how knowledge is taken up and how practices are coordinated in institutional settings (Smith, 2005). IE is interested in the coordinated work that individuals perform in their everyday lives to produce "the social"; in particular the knowledge that guides intentional efforts and the ruling relations that inform everyday interaction. This pursuit of understanding knowledge production and use on a daily basis is also of interest to racialization theorists who have an interest in discovering the racialized everyday interactions that create "the social" (Smith, 2005). Thus, ideas of everyday practices that create the social and the ways that these practices are governed by larger societal and institutional discourses are of great importance to race theorists. As a method of inquiry, institutional ethnography seeks to uncover how ruling relations inform these everyday practices.

\section{Methodology}

This paper presents data from a larger study investigating the experiences of racialized immigrant youth in the EJS program in Calgary, Alberta. The category of racialized immigrant youth, as used in this context, denotes youth ages 12-17 who are members of racialized groups and who are either first- or second-generation immigrants to Canada. As this is a diverse category, I do not aim to suggest how immigrant youth experience the Canadian justice system as a whole, but rather I examine and problematize the experiences of the cases presented in this research, as a means to shed light on some of the possible trends in the immigrant youth experience within the Canadian justice system. 
More work should be conducted, however, to further understand how these experiences differ based on racialized and immigrant status.

Data used in this paper were collected between 2013 and 2015. As is the tradition within IE, the study made use of ethnographic observations, interviews, and textual analysis. I conducted 10 observation sessions of the panel hearings and 10 sessions on the closing process, where the success of the cases is determined. Ethnographic data were collected and analysed using a relational ethnographic practice, whereby I was interested in establishing the power dynamics in the relations between the youth and the panel members (Desmond, 2014). In addition, I conducted five in-depth interviews with the youth and their families after the youth successfully completed the EJS program. I selected these youth based on their racialized and immigrant status, as a means of gaining insight into their experiences throughout their process of navigating the EJS program. Racialized immigrant status was determined based on self-identification during the panel process, whereby youth presented as racialized and were either first- or second-generation immigrants. Finally, I conducted six individual interviews and one focus group with five youth justice committee volunteers, as well as an additional six interviews with other participants of the process who occupy an administrative position. The goal of the interviews was to gain deeper insight into the processes that I observed during the hearings (Ritchie, Lewis, \& Elam, 2003).

As a former employer with the CYJS, I was able to engage in initial conversations about this project with the Executive Director. I submitted a proposal to request data and access to the youth justice committee hearings to the Alberta Solicitor General and Public Safety. My project was then vetted and approved by the University of Calgary's Conjoint Facilities Research Ethics Board and The Government of Alberta Solicitor General and Public Security. I emailed youth justice committee chairs asking them to invite me to their panel hearings; eight out of the 25 committees invited me to attend their panel hearings. Prior to the hearings, panel chairs extended the invitation to the youth and their family members to participate in the study. The youth were assured that their decision to participate in no way impacted the outcome of their cases. Pseudonyms are used for all participants in the study. Transcribed data and field notes were analysed using an interpretive thematic approach (Braun \& Clark, 2014). Data were coded once for initial themes, then a second time for emerging themes. During this process, interviews and focus group data were used to help explain the processes that took place during the panel hearings (Ritchie, Lewis, \& Elam, 2003). 


\section{Findings}

The following presents three key findings around key techniques used by racialized immigrant youth in their attempts to contest the definitions given to the during the panel hearings.

\section{Contested Definitions and Negotiated Meanings}

During the hearings, panel members engage in discussions with the youth and their families in order to provide an institutionally sanctioned account of the proceedings. This includes negotiations around the definition of terms and the accounts of the events, especially in cases where the youth's version of the events does not match the version provided to the committee in the police files. For example, I observed this in the case of 17-year-old Khalil, who attended his hearing on assault charges with his father, Nadir. During Khalil's own detailing of the events, panel members questioned him about his groups of friends. Michael (a panel member) questioned Khalil about the ethnic makeup of the group-Michael later explained in a debriefing session that this line of questioning was because he suspected Khalil was involved in a gang. Khalil indicated that his friends were almost exclusively Lebanese, seemingly confirming Michael's suspicion. Michael pushed Khalil by asking if it was an ethnic gang, to which Khalil responded no.

Michael continued to question Khalil and stated that by defending his friends through fighting, he could be seen as being in a gang as that is often how gangs start. Khalil insisted on defending his actions stating, "I am not involved in a gang or stupid behaviour, I was defending my friends." (Excerpt from field notes, December 13, 2014)

Khalil's definition of the incident was substantiated by his father, Nadir, who indicated that Khalil was not in a gang since he was "a good boy, a very good boy" whose only "problem" was his loyalty to his friends. Nadir further stated that he sees Khalil's need to defend his friends as his biggest challenge with him, indicating Nadir's acknowledgement that Khalil's strong loyalty to his friends can get Khalil into trouble. In stating this, Nadir reframed Khalil's behaviour as the overuse of a positive trait brought about by his loyalty to his friends, rather than as negative gang behaviour.

Despite their efforts, Khalil and Nadir's attempts to contest the definition of Khalil's behaviour were not successful. This can be seen in the conversation among the panel members during deliberations after Khalil and Nadir were asked to exit the room while the committee decided on appropriate sanctions: 
Michael noted that as a corrections officer, he is familiar with the characteristics of gangs; therefore, based on what Khalil stated he believed that he was in a gang... The panel expressed concern over the fact that Khalil felt that his actions were justified as he was defending his friends which led them to discuss issues around gang membership and community, while admitting that they were not sure that this group is a gang even though it had many of the characteristics. As a result, panel members spoke about this case and incident as if it was a gang case and discussed the Youth at Risk Development Program (YARD) as a possible consequence.

YARD is a program that provides support and intervention for youth ages 12-17 who are at risk of gang involvement. In addition to the discussion of the incident, panel members also discussed Khalil's objection to their questioning and his attitude as he responded. (Excerpt from field notes, December 13, 2014)

Based on these deliberations, it is clear that Khalil and Nadir were unsuccessful in convincing the panel that Khalil was not involved in gang activity, as the panel's deliberation discussion centred on Khalil's potential for gang activity. Further, Khalil's resistance to the line of questioning was interpreted as representing an "attitude," which prompted the committee to discuss the need for Khalil to undergo anger management. In the end, Khalil received sanctions of community services and a referral to the Restorative Action for Transformations program (RAFT), which is a program that facilitates victimoffender reconciliation where offenders are exposed to the impact of their actions on the victims. The decision to refer Khalil to RAFT rather than to YARD was based on Khalil's resistance to the idea that he was in a gang, which led the panel members to suspect that he would not be receptive to the YARD program. However, while explaining the consequences to Khalil and Nadir, panel members again reiterated their belief that he was a part of a gang, and suggested Khalil and Nadir look into the YARD program. In response to this, while Khalil and Nadir continued to contest these definitions, I observed Nadir disengage for the remainder of the discussions. The committee ultimately dismissed Khalil's claims and recommended treatment based on their own interpretation of Khalil's case.

Critical race theorists highlight the importance of providing a counter-narrative to the dominant account (Delgado \& Stefancic, 2017), which is further emphasised through my analysis of Khalil's case. That is, while panel members insisted on labelling Khalil's commitment to his friends as gang behaviour, Khalil and Nadir phrased Khalil's allegiance as loyalty. In discerning "the truth," panel members drew on the popular discourse of what constitutes a gang-i.e., the combination of youth, ethnicity, immigrant status, and violence, while rejecting the account presented by Khalil, which instead highlighted 
loyalty to one's friends. I argue that loyalty, which is understood as positive cultural capital, was redefined by those in power as negative capital, or gang membership, because Khalil "matched" the assumed notion of what constitutes a gang member. As noted earlier (O'Neill, 1998; Shan, 2013), this practice of negotiating definitions to make the youth's statements institutionally credible often takes place during interviews with service recipients in an attempt to make accounts fit into institutionally sanctioned language. In Khalil's case, my research shows the ways in which his own account was silenced in order to present an institutionally sanctioned account.

During observations, I saw most of the youth and their families attempt to renegotiate the accounts in the police report in order to present themselves in the most positive light. For many, such as in Khalil's case above, this was not successful. I observed a more successful experience of this renegotiation process, however, in the case of Rachel, a 17-year old non-racialized Canadian-born youth who attended her hearing with her grandfather. Rachel was referred to the EJS program due to trespassing charges. During her panel hearing, Rachel presented a very different account of the documented events:

Rachel noted that she was at a friend's house when he pulled out a gun and attacked her. She indicated that she did not cause the damage to the house; rather it was caused by the other friend who was there with her. Because she was the only one being charged, as she chose not to charge Trevor who attacked her with a gun, she questioned why she was here. Rachel was explaining what happened when her grandfather interrupted to clarify the story. He noted that Rachel was charged with trespassing by Trevor, who attacked her...he expressed that that seemed unjust...The panel pointed out that her story and the police report were different so they redirected the questioning to Rachel after her grandfather spoke...Rachel was responsive but not overly cooperative. She kept her answers short and brief only answering the questions asked without volunteering information to clarify the incident which made it confusing for everyone to follow. (Excerpt from field notes, September 12, 2014)

In this case, both Rachel and her grandfather, Sam, were comfortable voicing their objection with the charges. Furthermore, Sam often interrupted to express his thoughts, often reiterating his displeasure that Trevor was not charged. In addition, Rachel indicated that she would not admit to the charges as she was advised by a lawyer not to agree with anything in the police file. While the information in the police file was never discussed, the panel members remained unsatisfied with Rachel's account:

During the deliberations the panel members discussed Rachel's not taking responsibility for what was written in the police report (which remains the official record of what happened). Her story was different from the police report and 
therefore it was interpreted as her not accepting responsibility for the events. Members also discussed the fact that Rachel spoke to a lawyer prior to the hearing. After discussion, it was decided that the committee would return her file to the Calgary Youth Attendance Centre (the body representing Alberta Justice and Solicitor General in Calgary) and not proceed with the EJS process... After Rachel and Sam retuned to the room the panel explained why they could not proceed with the program as Rachel was not accepting what was in the police report. The family was understandably upset at this point. Her grandfather stepped in once again to defend Rachel's decision and emphasized that the program is meant to be supportive of youth rather than punitive, which would be the case if she disagreed with the police report. The panel advised Rachel that if she had disputes with the police report it would be in her best interest to get a lawyer to present her version of the incident. (Excerpt from field notes, September 13, 2014)

In this case, Rachel and Sam were successful in contesting the official account of the events and in providing a different account of what occurred. In addition, they used an available resource, a lawyer, in an attempt to have Rachel's version of the story recognized as truth during the panel hearing. Based on this discussion, Rachel was advised that she could further contest the police version with her lawyer. It is important to note that this option is not given to youth who are referred to the EJS program, since their acceptance of responsibility means that they are implicitly agreeing to the official account of the incident. In this case, Rachel was successful in challenging the official account of the situation, giving her the ability to defend her case in the court process.

This discussion highlights different ways that cultural capital is used to make a compelling argument. I argue that Rachel's advantage, and the panel's receptiveness to Rachel's challenging of the official account of her offense, was made possible by Rachel's capital, which allowed her and her grandfather to converse confidently at the panel hearing, and do so from the comfort that is embodied in being a non-racialized Canadianborn youth (i.e., having the feel for the game) and her knowledge of the justice system. Their knowledge and comfort level of the justice system were reflected in the fact that they consulted a lawyer, which meant that their case would be dismissed from the EJS Program, thus giving Rachel the ability to contest her responsibility for the offence in the court process. This suggests that when racialized immigrant groups are seen to lack the appropriately recognised capital within justice field, they lose the ability to successfully contest the accounts that are written about them (Balzarini, 2006; Banston, 2004; Barns, 2010; Caldas \& Cornigans, 2014; Cui 2015; Lareau, 2015). 


\section{Contested Definitions, Direct Exclusion, and Self-elimination}

According to Lamont and Lareau (1988), when cultural capital is lacking from social processes, participants experience exclusion or elimination rather than attempt to contest the definitions that have been assigned to them. Language is a common form of capital that often disadvantages those who do not share the dominant language (Kayaalp, 2016; Tomic, 2011). The EJS process emphasizes the importance of open and fluent conversation during hearings as a means of knowledge transmission. Such conversation, my research shows, provides the youth and their families the opportunity to present their account as well as provides the panel more information on the background of the youth. In this study, I observed that participants whose first language was not English were removed or removed themselves from the hearing process. This was seen with Raj, a 16-year-old male from India who was referred to the EJS program for charges of theft under $\$ 5,000$. Raj attended the hearing with his father and his sister, who translated the proceedings for their father, as he was not fluent in English. I recorded the following field notes during Raj's hearing:

Raj's father showed some difficulty understanding the conversation as panel members attempted to explain the process to him; instead Raj and his sister stepped in to translate. Once everyone was satisfied that Raj's father understood what was taking place, Raj and his father entered the room where the hearing was being held...during the proceedings the panel members continued to question whether or not Raj's father was understanding the process as he demonstrated some language barriers. The panel members then called for Raj's sister to come into the room in order to translate for Raj's father...the hearing processed in a question/answer style and was not very conversational with little advocacy offered on Raj's behalf. (Excerpt from field notes, July 17, 2013)

As a result of Raj's father's inability to actively engage in conversation, Raj's hearing was less conversational, which I contend placed Raj in a disadvantaged position since these conversations allow panel members to gain insight into the youth and their worldview.

Amir, a 15-year-old male whose parents were from Algeria, had a similar experience during his panel hearing. Amir was sent to the EJS program for charges of theft under $\$ 5,000$. Amir appeared at the hearing with his father. Initially the panel members were concerned about Amir's father's level of understanding of English, as he was not very responsive to many of the questions. Nevertheless, when questioned Amir's father indicated that he was following the process. However, during the hearing, there were occasions where Amir spoke to his father in their mother tongue: 
At times during the panel Amir interrupted the process to have conversations with his father in their mother tongue, the panel members do not question what is being discussed but attempt to ensure that Amir's father is understanding the process.

During the deliberations, one panel member acknowledged the language barrier and questioned whether or not Amir's father was able to fully follow the proceedings. The members discuss this topic and then continue with the deliberation, appearing satisfied Amir's father understood the processed due to Amir's translation. (Excerpt from field notes, July 28, 2013)

In both Raj and Amir's cases, panel members expressed concerns about language barriers, but as panel members are not provided with adequate training to address language barriers during panel hearings, nothing was done to address these barriers or the potential impact they had on panel hearings.

Likewise, when Kwan, a 13-year-old male from South Korea appeared at the hearing with his mother, his mother demonstrated difficulty communicating in English. While Kwan was able to fully articulate his feelings during the interview, his mother often struggled to express herself, which resulted in Kwan often stepping in to speak for her. This reversed the usual roles, where parents are the ones to speak on behalf of and advocate for their children. Khalil's father Nadir also struggled to fully communicate with the panel. Many times during his hearing he began to respond to questions, however he subsequently dismissed the conversation as panel members questioned him to get an understanding of what he was communicating. Similarly, when Zion, a 12-year-old male from Egypt, and his father were providing their account, Zion's father often struggled to find the right words to express himself. In all these cases, parents removed themselves or were excluded from conversations, which meant that they were also not actively engaged in the overall panel proceeding and could not advocate for their children.

In cases of inadequate language capital, I observed varying types of social exclusion. First, there was direct exclusion as families who lacked recognised language skills remained on the outside of the process, never fully able to participate in the process. I also saw family members in such circumstances demonstrate self-elimination as they removed themselves from the process in cases. This resulted in compliance, which I witnessed with many of the racialized immigrant families. Moreover, many times these family members insisted that they were understanding the process, even as they remained disengaged and had to communicate with the panel members through their children.

According to CRT, when language is used as a form of capital to exclude racialized immigrant groups, this is done at the expense of the potential benefits of holding multiple language frameworks (Tomic, 2011). I contend that the dangers of this form of exclusion 
in the EJS process are important to note. First, it inhibits the ability of the youth and their families to provide their own account of the events. As noted above, this is a crucial part of the EJS program as youth must be able to accept responsibility for the account that is articulated in the police report. Without the ability to advocate for themselves or through family members, youth are placed at a disadvantage of accepting the account in the police report, whether or not they are in agreement. As a result, they lose the legal right to challenge the official police account. The second implication is that the youth's counternarrative remains missing from the official discourse, as the youth and their families are unable to "have their voices heard." This further silences these voices within the dominant discourse, and limits their ability to change or contribute to the dominant discourses. Whether through direct exclusion or self-elimination, I argue, these accounts and voices remain on the periphery of institutional and societal discourse, further placing racialized immigrant youth at a disadvantage within the justice system.

\section{Learning to Value All Forms of Cultural Capital}

During the EJS process, sanctioned cultural capital can aid in equalizing power imbalances between panel members and the youth and their families. The ability for youth and panel members to draw on shared capital allowed the panel and youth to connect in a way that gave the panel members a fuller understanding of the youth and their argument. In the absence of shared cultural capital, it is challenging for committee members and the families to produce an account of the situation that is acceptable to both parties. For example, when Seth, an Indigenous 12-year-old male appeared at his hearing for theft under $\$ 5,000$ charges, he provided information about being bullied at school due to his race. While he spoke of this, Seth became emotional and began to cry; the response from one of the male panel members, Cedric a Black male, was to provide comfort and understanding to Seth:

Panel members explained that youth justice committees have their origin in First Nations communities as a means of encouraging Seth. The panel was able to personally connect with the youth's struggles as all but one were racialized individuals. Panel members reinforced the need to be proud of his heritage; Cedric, a Black male, was the most vocal at this time, as he explained to Seth that he has also experienced racism and knew how it felt. (Excerpt from field notes, June 17, 2013)

In addition to the reassurance offered to Seth, Cedric drew on his experiences as a Black male to encourage him. 
Similarly, I observed other cases where other panel members drew on their own cultural capital to connect with youth from similar backgrounds:

Jamil, a panel member from India, showed some cultural understanding of the emotion that was being expressed by the family, especially the father. He spoke directly to the father, expressing that he understood that this situation was embarrassing to the family. (Excerpt from field notes, June 17, 2013)

I also witnessed this act of drawing upon the available common cultural capital in Kyle's case, where a volunteer drew on his own cultural experiences and similar cultural understandings to interpret Kyle's feelings and reactions when Kyle's was unable to adequately explain himself:

Kyle resides with mom and his step father...Akil later discussed with the panel that the fact that Kyle lived with stepdad in his culture, could be a factor in him feeling estranged and not feeling like he belonged. Akil noted that in their culture being the man of the house comes with a lot of responsibility which Kyle may have assumed after father left, this may have created tension at home once his mother remarried. In addition, it is often difficult to reconnect with an adult who is not the biological father. Akil suggested that Kyle may feel a lack of belonging and some estrangement at home which also translates to his life at school. (Excerpt from field notes, September 13, 2014)

Finally, I also saw instances of appealing to a common heritage and similar experiences as a form of cultural capital in cases with non-racialized Canadian-born youth. For example, in the case of Cole, a panel member connected with Cole's mother, Kimberly, during the hearing process because of a common past:

I noticed that Susan was much more relaxed and conversational from the onset, making jokes with the family and really engaging them. This appeared to impact the process and the response of the family as they opened up quite a bit...Kimberly was a lot more engaged and spoke on behalf of Cole rather than just speaking to defend him or elaborate on what he has said - she often spoke up on behalf of her son...Susan was also more engaged with Kimberly and spoke to her rather than always redirecting the questions to Cole. Susan was very supportive and responsive to this family. (Excerpt from field notes, December 13, 2014)

I noticed that Susan often addressed Kimberly in a more personal way than she had with other youth and their families. During the debrief session Susan noted that she felt connected to Kimberly because she could relate to her experiences as she too had a daughter who, as she described, had made "poor decisions." 
My research demonstrates that having shared cultural capital helped the families present themselves in a way that was understood and accepted by the panel members. What happens when no shared cultural capital exists between the youth, their families, and the panel members? My observations suggest that there needs to be an intentional attempt to ensure that panels can represent community diversity in order to empower participants in the EJS program to fully engage in the process and experience more successful outcomes.

\section{Discussion: Challenging Power Relations During Panel Hearings}

Within the EJS process youth justice committee, volunteers are placed at the interface of the community and the justice system, and are called to represent both the community in the justice process, but also the justice system as they interact with the community. The importance of sharing the appropriate cultural capital is seen in cases where youth and their families attempted to contest the accounts that were provided in the official police report. My research suggests that in cases where the families possess "a feel for the game" these attempts were more successful, as was the case with Rachel.

However, my research also shows that when the cultural capital that the youth and their families possessed did not fit within the field in which they were trying to navigatein this case the EJS program and broader criminal justice system-youth were placed at a disadvantage. In cases such as Khalil's, youth were unsuccessful in having their counternarrative viewed as credible. In addition, family members were not recognised as crucial and valuable advocates in the EJS process. In these cases, the youth were left to translate on behalf of their parents, making the youth the sole voice in their own defence, while their parents were excluded from the discussions based on a perceived lack of suitable cultural capital. However, as noted in the cases of Rachel and Cole, when their parents possessed the necessary language capital and were fully able to engage in the process, the EJS process unfolded to the benefit of the young person.

By examining the concept of cultural capital, this study aimed to identify if and how members of the racialized immigrant community faced challenges when presenting their claims within the EJS program. There is not a single solution to these challenges, as more work needs to be done to investigate the ways that various forms of cultural capital, including language, race, ethnicity, immigrant status, and the experiences that are associated with these variables impact the experiences of racialized immigrant youth within the EJS program. This work would also need to focus on the particulars of the different groups presented under the broad category of "racialized immigrant." This paper contributes to these efforts by highlighting some of the ways in which a lack of accepted 
cultural capital negatively impacts racialized immigrant youth and causes them to experience unique challenges within the justice process.

\section{Future research}

Despite the compelling evidence provided in this study, there were some limitations to this research. First, due to the available sample, only one female youth was included in this paper. It would be beneficial to further investigate the impact of gender on contesting definitions for both racialized immigrant and non-racialized Canadian-born youth. Second, as noted above, the category of racialized immigrant was broadly defined in this research. Future research is needed to determine if the process of contesting definitions varies for different racialized and/or immigrant groups; for example racialized Canadian-born youth. Further, only one Indigenous voice was included in this study, and additional research should investigate the experiences of Indigenous youth in contesting definitions within diversion programs and navigating the broader criminal justice system.

\section{Conclusion}

Critical race theory stresses the importance of providing marginalized groups the opportunity to have their accounts heard in a manner that is true to their experiences in the social world and in institutional settings. It is important that these voices be included into the dominant discussion in order to prevent symbolic violence. Without this, the harm that is caused through the exclusion and self-elimination of these individuals from the dominant society is perpetuated within institutions such as the justice system. I argue that these voices need to be included, and to do so requires a rethinking of how symbolic capital is treated in Canadian society. This requires 1) recognising the value of having diverse voices, languages, and worldviews contributing to the dominant discourse; 2) acknowledging that the lack of diverse representation, on panels and elsewhere, prevents racialized immigrant individuals from being fully engaged in their hearing and thus hinders restorative justice; and 3) ensuring that institutions, including the justice system, provide its employees and volunteers with the ability to reflect on and challenge the power dynamics within institutional processes that create barriers for racialized and immigrant families. I argue that, rather than focusing on narrowly defined ideas of valuable cultural capital, institutions must broaden their understanding of the value of various forms of cultural capital possessed by diverse groups in order to be truly inclusive. 


\section{References}

Alberta Justice and Solicitor General. (2003). Youth Diversion. Retrieved from https://justice.alberta.ca/programs_services/criminal_pros/crown_prosecutor/Pages/ youth_diversion.aspx.

Albrecht, B. (2010). Multicultural challenges for restorative justice: Mediators' experiences from Norway and Finland. Journal of Scandinavian Studies in Criminology and Crime Prevention, 11, 3-24.

Archibald B., \& Llewellyn J. (2006). The challenges of institutionalizing comprehensive restorative justice: Theory and practice in Nova Scotia, Dalhousie Law Journal, 29, 297-343.

Balzarini, J. (2006, August). Social capital, race and political participation. Paper presented at the American Sociological Association Annual Meeting, Montreal, QC.

Bankston, C. (2004). Social capital, cultural values, immigration, and academic achievement: The host country context and contradictory consequences. Sociology of Education, 77(2), 176-179.

Bala, N. (2003). Diversion, conferencing and extrajudicial measures for adolescent offenders. Alberta Law Review, 40(4), 991-1027.

Barn, R. (2010). Care leavers and social capital: Understanding and negotiating racial and ethnic identity. Ethnic and Racial Studies, 33(5), 832-850.

Bell, S. (2011). Young offenders and youth justice: A century after the fact $\left(5^{\text {th }} \mathrm{ed}\right.$.). Toronto, ON: Nelson Education Ltd.

Bourdieu, P. (1977). Cultural reproduction and social reproduction. In J. Karabel, \& A. H. Halsey (Eds.), Power and ideology in education (pp. 487-509). New York, NY: Oxford University Press.

Bourdieu, P. (1984). Distinction: A social critique of judgment of taste. Cambridge, MA: Harvard University Press.

Bourdieu, P. (2013). Symbolic capital and social classes. Journal of Classical Sociology, 13(2), 292-302.

Brondolo, E., Libretti, M., Rivera, L., \& Walsemann, K., (2012). Racism and social capital: The implications for social and physical well-being. Journal of Social Issues, 68(2), 358-384.

Brown, S. L. (2019). Cultural wealth: Key factors of success for Canadian women of colour in a doctoral program. Journal of Critical Race Inquiry, 6(1), 62-89.

Calgary Youth Justice Society. (2008). The Youth Justice Committee Program. Retrieved from http://calgaryyouthjustice.ca/what-we-do/youth-justice-committee/ 
Caldas, S., \& Cornigans, L. (2015). Race, ethnicity and social capital among the middle and upper classes: A structural equation model. School Community Journal, 25(1), 137-156.

Campbell, K. (2007). What was it they lost? The impact of resource development on family violence in a Northern Alberta community. Journal of Ethnicity in Criminal Justice, 5(1), 57-80.

Choi, J. J., \& Margaret S. (2009). Toward a culturally competent restorative justice practice framework: A focus on Asian Americans. Journal of Contemporary Social Services, 90(4), 400-406.

Clairmont D., \& Kim E. (2013). Getting past the gatekeepers: The reception of restorative justice in the Nova Scotian criminal justice system. The Dalhousie Law Journal, 36(2), 359-391.

Crocker, D. (2013). The effects of regulated discretion on police referrals to restorative justice. The Dalhousie Law Journal, 36(2), 393-418.

Cui. D. (2015). Capital, distinction, and racialized habitus: Immigrant youth in the educational field. Journal of Youth Studies, 18(9), 1154-1169.

Day, J., \& McDonald, S. (2010). Not so fast, my friend: Social capital and the race disparity in promotions among college football coaches. Sociological Spectrum, 30(2), 138-158.

De Freitas, E., \& McAuey, A. (2008). Teaching for diversity by troubling whiteness: Strategies for classrooms in isolated white communities. Race, Ethnicity and Education, 11(4), 429-442.

Delgado, R. (1994). Rodrigo's eighth chronicle: Black crime, white fears. On the social construction of threat. Virginia Law Review, 80(2), 503-548.

Delgado, R. (2000). Goodbye to Hammurabi: Analyzing the atavistic appeal of restorative justice. Stanford Law Review, 52(4), 751-775.

Delgado, R. \& Stefancic, J. (2017). Critical race theory: An introduction (2nd ed.). New York: NYU Press.

Desmond, M. (2014). Relational ethnography. Theoretical Sociology, 43, 547-579.

DuBois, W.E.B. (1903). The souls of Black folks. Chicago, IL: Dover Publications, Inc.

Fernando, S., \& Rinaldi, J. (2017). Seeking equity: Disrupting a history of exclusionary immigration frameworks. Canadian Ethnic Studies, 49(3), 7-27.

Gavrielides, T. (2014). Bringing race relations into the restorative justice debate: An alternative and personalized vision of "the other." Journal of Black Studies, 45, 216-246.

Gonzales, L. (2012). Stories of success: Latinas redefining cultural capital. Journal of Latinos and Education, 11, 124-138. 
Goodman, P. (2008). "It's just Black, white, or Hispanic": An observational study of racializing moves in California's segregated prison reception centers. LaW and Society Review, 42(4), 735-770.

Government of Canada Ministry of Justice. (2002). Youth Criminal Justice Act. Retrieved from Government of Canada website: http://laws-lois.justice.gc.ca/PDF/Y-1.5.pdf

Gutzmore, C. (1983). Capital, 'Black youth' and crime. Race and Class, 25(2), 13-30.

Hartmann, D. (2015). Reflections on race, diversity and the crossroads of multiculturalism. The Sociological Quarterly, 56, 623-639.

Hogeveen, B. (2005). Toward "safer" and "better" communities: Canada's Youth Criminal Justice Act, Aboriginal youth and the process of exclusion.” Critical Criminology, 12, 287-305.

Hogeveen, B. (2006). Unsettling youth justice and cultural norms: The Youth Restorative Action Project. Journal of Youth Studies, 9(1), 47-66.

James, C. (2009). African-Caribbean Canadians working "harder" to attain their immigrant dreams: Context, strategies, and consequences. Wadabagei: A Journal of the Caribbean and Its Diasporas, 12(1), 92-108.

Kayaalp, D. (2016). Living with an accent: A sociological analysis of linguistic strategies of immigrant youth in Canada. Journal of Youth Studies, 19(2), 133-148.

Khanlou, N. (2008). Psychosocial integration of second and third generation racialized youth in Canada. Canadian Diversity, 6(2):54-57.

Lamont, M., \& Lareau, A. (1988). Cultural capital: Allusions, gaps and glissandos in recent theoretical developments. Sociological Theory, 6, 153-168.

Lareau, A. (2015). Cultural knowledge and social inequality. American Sociological Review, 80(1), 1-27.

Malachowski, C., Skorobohacz, C., \& Stasiulis, E. (2017). Institutional Ethnography as a method of inquiry: A scoping review. Qualitative Sociology Review, 13(4), 84-121.

Maristela, Z. (2014). Converting capital: The experiences of Latinas/os in graduate health care programs. The Qualitative Report, 19(85), 1-26.

Milner, H. R., \& Howard, T. C. (2013). Counter-narrative as method: Race, policy and research for teacher education. Race Ethnicity and Education, 16(4), 536-561.

Moran, L. (2016). Constrictions of race: Symbolic ethnic capital and the performance of youth identity in multicultural Australia. Ethnic and Racial Studies, 39(4), 708-726.

Morrison, B., \& Colleen P. (2012). Juvenile justice and restorative justice: Reflecting on developments in British Columbia. In J. Winterdyk \& R. Smandych (Eds.), Youth at risk and youth justice: A Canadian overview (pp. 358-378). Toronto, ON: Oxford University Press. 
Mykhalovskiy, E., \& McCoy, L. (2002). Troubling ruling discourses of health: Using institutional ethnography in community-based research. Critical Public Health, 12(1), 17-37.

O’Neill, B. (1998). Institutional Ethnography: Studying institutions from the margins. Journal of Sociology and Social Welfare, 25, 127-144.

Oriola, T., \& Adeyanju, C. T. (2011). Perceptions of the Canadian criminal justice system among Nigerians: Evidence from a local church in Winnipeg, Manitoba, International Journal of Human Sciences, 8(1), 635-656.

Park, J. (2012). Asian American women's perspectives on historically white sorority life: A critical race theory and cultural capital analysis. Oracle: The Research Journal of the Association of Fraternity/Sorority Advisors, 7(2), 1-18.

Peirone, A., Maticka-Tyndale, E., Gbadelo, K., \& Kerr, J. (2017). The social environment of daily life and perceptions of police and/or court discrimination among AfricanCaribbean, and Black youth. Canadian Journal of Criminology and Criminal Justice, 59(3), 36-372.

Razak, N. (2009). Decolonizing the pedagogy and practice of international social work. International Social Work, 52(1), 9-21.

Ritchie, J., Lewis, J., \& Elam, G. 2003. Designing and selecting samples. In J. Ritchie, \& J. Lewis (Eds.), Qualitative research practice: A guide for social science students and research (pp. 77-108). London: Sage Publications.

Samuels, K. (2015). Examining the utility of pre-charge youth diversion programs: A Canadian context. (Master's thesis). University of Ontario Institute of Technology. Toronto, ON.

Shan, H. (2013). Skill as a relational construct: Hiring practices from the standpoint of Chinese immigrant engineers in Canada. Work, Employment and Society, 27(6), 915-931.

Smith, D. (2005). Institutional ethnography: A aociology for the people. Lanham, MD: AltMira Press.

Smith, D. (2006). Institutional ethnography as practice. Lanham, MD: Rowman and Littlefield Publishers, Inc.

Tomic, P. (2011). The colour of language: Accent, devaluation and resistance in Latin American immigrant lives in Canada. Canadian Ethnic Studies, 45(1), 1-21.

Walby, K. (2005). How closed-circuit television surveillance organizes the social: An institutional ethnography. Canadian Journal of Sociology, 30(2), 189-214.

Williams, M. (2013). African Nova Scotian restorative justice: A change has gotta come. Dalhousie Law Journal, 36(2), 419-459. 
Wortley, S. (2009). Introduction. The immigration-crime connection: Competing theoretical perspectives. Journal of International Migration and Integration, 10(4), 349-358.

Wortley, S., \& Owusu-Bempah, A. (2009). Unequal before the law: Immigrant and racial minority perceptions of the Canadian Criminal Justice System. Journal of International Migration and Integration, 10(4), 447-473.

Yosso, T. J. (2006). Whose cultural has capital? A critical race theory discussion of community cultural wealth. Race, Ethnicity and Education, 8(1), 69-91. 